\title{
Adsorption of Zinc Contained in the Poultry Feedstuff onto Clinoptilolite
}

\author{
E. ŠUCMAN ${ }^{1}$, J. PÁC̆ $\check{C}^{1}, \mathrm{~K}$. BRZOSKOVÁ2, M. VÁVROVÁ², P. KETTISCH ${ }^{3}$ \\ ${ }^{1}$ Department of Biochemistry and Biophysics, Faculty of Veterinary Hygiene and Technology \\ University of Veterinary and Pharmaceutical Sciences Brno, Brno, Czech Republic \\ ${ }^{2}$ Faculty of Chemistry, Brno University of Technology, Brno, Czech Republic \\ ${ }^{3}$ Anton Paar GmbH, Graz, Austria \\ Received November 6, 2006 \\ Accepted April 26, 2007
}

\begin{abstract}
Šucman E., J. Páč, K. Brzosková, M. Vávrová, P. Kettisch: Adsorption of Zinc Contained in the Poultry Feedstuff onto Clinoptilolite. Acta Vet. Brno 2007, 76: S39-S44.

The aim of this work was to find whether an adsorbent used as an additive in the feed mixtures could influence the concentration of free available zinc. The feed supplement ZeoFeed, which often constitutes a part of animal feed mixtures, mainly for poultry, was used as adsorbent in the amount of $10 \mathrm{~g} \cdot \mathrm{kg}^{-1}$ of the feed mixture. A substantial part of ZeoFeed is clinoptilolite, a natural form of zeolite.

Two sample preparation methods were used for the determination of zinc. The microwaveassisted wet digestion method was used to achieve a complete decomposition of the feed mixture in order to determine the total zinc concentration. The extraction method represented a simplified model of the processes in the digestive fluid tract. The extraction was done under laboratory temperature for 30,60 and $120 \mathrm{~min}$. Concentrations of zinc both in digests and extracts were determined by the method of the differential pulse anodic stripping voltammetry.

The total zinc concentration (mean $\pm 95 \%$ confidence interval) in the feed mixture without addition of clinoptilolite was found to be $145 \pm 32.0 \mathrm{mg} \cdot \mathrm{kg}^{-1}$ and in the feed mixture with added clinoptilolite $146 \pm 11.5 \mathrm{mg} \cdot \mathrm{kg}^{-1}$.

The concentrations of free available zinc were approximately ten times lesser than the total amount. The analysis of extracts showed that no statistically significant differences between concentrations of zinc in extracts without clinoptilolite and with clinoptilolite addition have been found. The extraction time did not affect the extracted amount of zinc significantly.

In addition to zinc, also other three trace elements, namely the essential trace element copper and the toxic trace elements cadmium and lead, were measured. However, these data have only preliminary value and need further verification.
\end{abstract}

Adsorbents, microwave-assisted digestion, stripping voltammetry, trace elements

It is well known that the feeding of farm animals is one of the most important factors deciding the quality and/or safety of produced foods. The quality of feedstuffs and rational set up of feed rations are basic presumptions for high efficiency, production health and economic prosperity in the breeding.

Important constituents of feedstuffs today are various kinds of additives, among them also adsorbents. These are added to feed mixtures in order to improve the health conditions of animals and/or to improve the conditions of their environment. One of the adsorption substances, used very often nowadays is clinoptilolite. It is hydrated aluminosilicate of calcium, potassium, sodium and magnesium. Its crystal lattice is formed by tetrahedrons of $\left(\mathrm{SiO}_{4}\right)^{4-}$ mutually connected by atoms of oxygen. Additionally, atoms of aluminium may substitute some silicon atoms and consequently $\left(\mathrm{AlO}_{4}\right)^{5-}$ groups are formed. Dimensions of channels existing under such structure are large enough to be able to accept molecules having the size of up to a few tenths of nanometers. The effective diameter was found to be $0.4 \mathrm{~nm}$. The volume of such channels forms $24-30 \%$ of the total volume (Zeocem 2006).

Principally, there are at least two important reasons why adsorbents are used. The first one

Address for correspondence:

Prof. RNDr. E. Šucman, CSc.

University of Veterinary and Pharmaceutical Sciences Brno

Palackého 1-3, 61242 Brno, Czech Republic
Phone: +420541562603

E-mail: sucmane@ vfu.cz

http://www.vfu.cz/acta-vet/actavet.htm 
is based upon their ability to adsorb some harmful substances, e.g. mycotoxins. The second one is their favourable effect on the stable environment, where especially concentrations of ammonia can be substantially reduced. Consequently, better production results can be achieved (Olver 1997; Huwig 2001; Tomaševic-Čanovic et al. 2001; Melenová et al. 2003; Cabuk et al. 2004; Suchý et al. 2006).

On the other hand, one must be sure, that at the same time when the above-mentioned desirable effects of adsorbents are occurring, adsorption processes connected with decreases in concentration of nutritionally important substances do not occur. As an example of such substances, trace elements may be named. Among essential trace elements, zinc plays an important role due to its participation in many enzyme and/or hormone processes (Karlson 1994). The possible consequences of zinc deficiencies have been described e.g. by Jantošovič (1995) and Jurajda (2003).

The aim of this work was to realise a model experiment in order to prove the possibility of zinc adsorption from feedstuffs containing clinoptilolite.

\section{Materials and Methods}

Instruments

The high pressure microwave-assisted digestion of samples was done using the Multiwave 3000 (Anton Paar, Austria), provided with two rotors. The $8 \mathrm{SFX}$ digestion rotor equipped with thick wall quartz vessels and the 8EVAP evaporation rotor.

The shaking machine LT 2 (Sklo union, Czech Republic) was used for extractions.

The voltammetric determinations of zinc concentrations were done by the ETP 30 polarographic equipment (Polaro-Sensors, Czech Republic) with control software Polar 5.1 (Polaro-Sensors, Czech Republic) The threeelectrode mode was used, the hanging mercury drop electrode (HMDE) being the working electrode.

\section{Chemicals}

Both samples and standard solutions vere prepared using the ultra pure water (NANOpur Barnstead, USA) having the specific conductivity less then $1 \mu \mathrm{S} \cdot \mathrm{m}^{-1}$. All chemicals were of Suprapur grade (Merck, FRG). Compressed argon 4.6 UN 1006, GA 260 (Linde Technoplyn, Czech Republic) was used.

Furthermore, the HMDE was filled up with Mercury for Polarography (Merck, FRG) and the solution of 3 $\mathrm{mol} \cdot \mathrm{l}^{-1} \mathrm{KCl}(\mathrm{ORION}$ Research, USA) was used in the reference electrode.

Analytical standards were prepared daily fresh from the $1.000 \mathrm{~g} \cdot \mathrm{l}^{-1}$ store solutions Astasol (Analytika, Czech Republic)

Samples

Feed mixture 301-N1-Bovans Goldline (Agrokonzulta, Czech Republic) and the adsorbent additive ZeoFeed (ZEOCEM, Slovak Republic) in the amount of $10 \mathrm{~g} \cdot \mathrm{kg}^{-1}$ of the feed mixture were used.

Microwave-assisted digestion

The $0.5 \mathrm{~g}$ of the sample was mixed with $6 \mathrm{ml}$ of the digestion mixture in the digestion vessel. The mixture contained concentrated $\mathrm{HNO}_{3}, \mathrm{H}_{2} \mathrm{O}_{2}$ and $\mathrm{HCl}(12+12+1)$. The sample was digested for 85 min at $280{ }^{\circ} \mathrm{C}$ using the digestion parameters given in the Table 1 . The digestion vessels were then transferred into the evaporation rotor and the liquid was evaporated to dryness. The appropriate parameters are also given in the Table 1 . The residue after evaporation was dissolved in $10 \mathrm{ml}$ of ultra pure water containing $40 \mu \mathrm{l}$ of $\mathrm{HNO}_{3}\left(6 \mathrm{~mol} \cdot \mathrm{l}^{-1}\right)$.

Table 1. Digestion and evaporation parameters used for Multiwave 3000

\begin{tabular}{|l|c|c|c|c|}
\hline Step & Power [W] & Ramp time [min] & Hold time [min] & Cooling level \\
\hline Digestion & 400 & 5 & 5 & 1 \\
\hline 1 & 800 & 5 & 50 & 3 \\
\hline 2 & 0 & 0 & 30 & 3 \\
\hline 3 & 900 & 0 & 25 & 1 \\
\hline Evaporation & 0 & 0 & 30 & 3 \\
\hline 1 &
\end{tabular}

Extraction

The simplified model for extraction using $0.01 \mathrm{~mol} \cdot \mathrm{l}^{-1} \mathrm{HCl}$ was used. Under laboratory temperature $\left(22 \pm 2{ }^{\circ} \mathrm{C}\right)$ $2 \mathrm{~g}$ of the feed mixture both without and with the adsorbent in the $250 \mathrm{ml}$ Erlenmeyer flask have been extracted by 
$100 \mathrm{ml}$ of $\mathrm{HCl}$ for 30, 60 and 120 min particularly. After each elapsed extraction time the aliquot volume of $0.1 \mathrm{ml}$ was taken away, which was further analysed for the trace elements content.

Using both digestion and extraction procedures, at least five independent samples have been prepared.

Voltammetric measurements

The voltammetric trace elements determination was done by differential pulse anodic stripping voltammetry (DPASV) using the technique of standard addition. An aliquot of $100 \mu 1$ of extract or $50 \mu 1$ of dissolved evaporation residue was mixed with $10 \mathrm{ml}$ of the acetate buffer $(\mathrm{pH}=5.6)$ and measured. The following instrumental parameters were applied: deposition potential $-1.1 \mathrm{~V}$, final potential $0.15 \mathrm{~V}$, scan rate $20 \mathrm{mV} / \mathrm{s}$, drop time $0.2 \mathrm{~s}$, pulse width $100 \mathrm{~ms}$, pulse height $50 \mathrm{mV}$, deposition time $180 \mathrm{~s}$, rest time $15 \mathrm{~s}$.

At least two determinations in the voltammetric cell have been done. For subsequent calculations the mean of these parallel measurements was taken.

There is not any certified reference material available for such samples. Therefore, the accuracy of results was checked by the method of standard addition. The amount of the standard added, exceed the amount of the analyte in the sample approximately two times.

The statistical evaluation of results was done according to Eckschlager et al. (1992).

\section{Results and Discussion}

The examples of measured voltammetric curves are given in Fig. 1 for a digested sample and in Fig. 2 for an extracted sample. It should be mentioned that no effect of the adsorbent addition was found upon the shape of the voltammetric curves both in the case of the digestion and extraction.

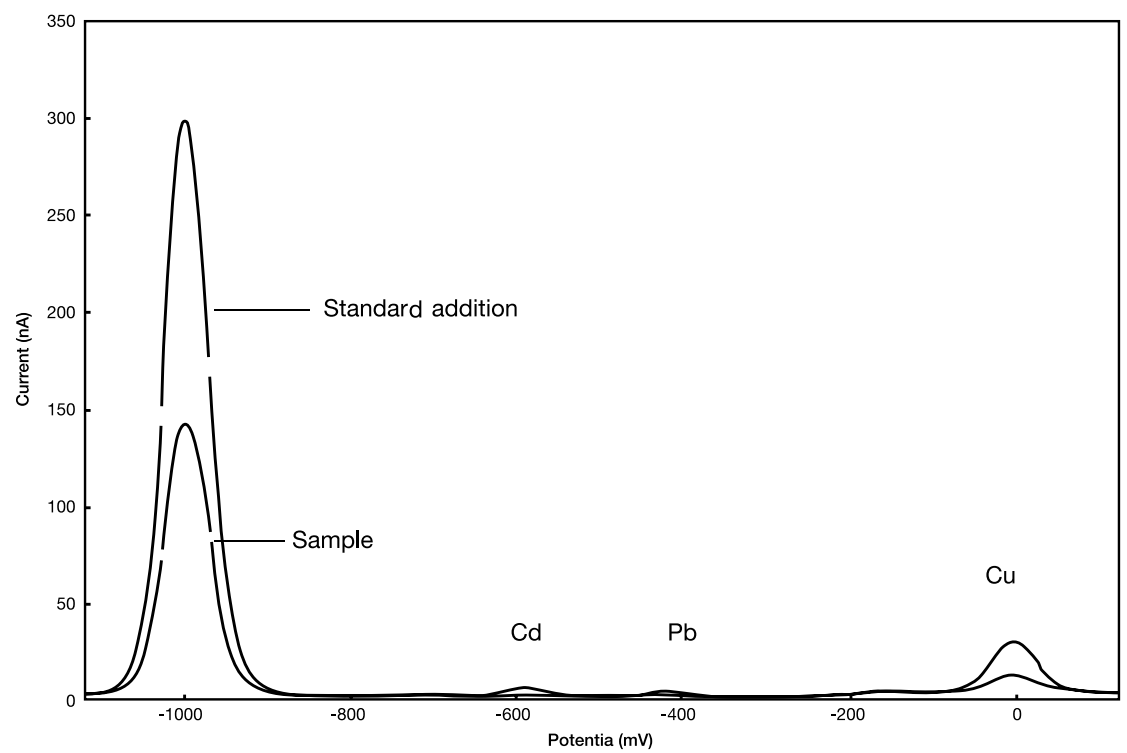

Fig. 1. Voltammetric curves for digested feedstuff sample without addition of adsorbent

As seen both in Fig. 1 and Fig. 2, the applied measurement procedure also enabled the determination of three other trace elements, namely copper, cadmium and lead. Nevertheless, the measurement conditions for these elements have not been optimized yet. Therefore, these results had only approximate value and are not included in this work.

In all determinations both in case of digested and extracted samples more than $90 \%$ of the added amount of zinc standard was found. Therefore, under experimental conditions used in this work the accuracy of results may be assumed to be satisfactory. The relatively higher variability may be explained by the inhomogenity of the feed mixture. In future work an improvement in the field of sample homogenity will be required. 


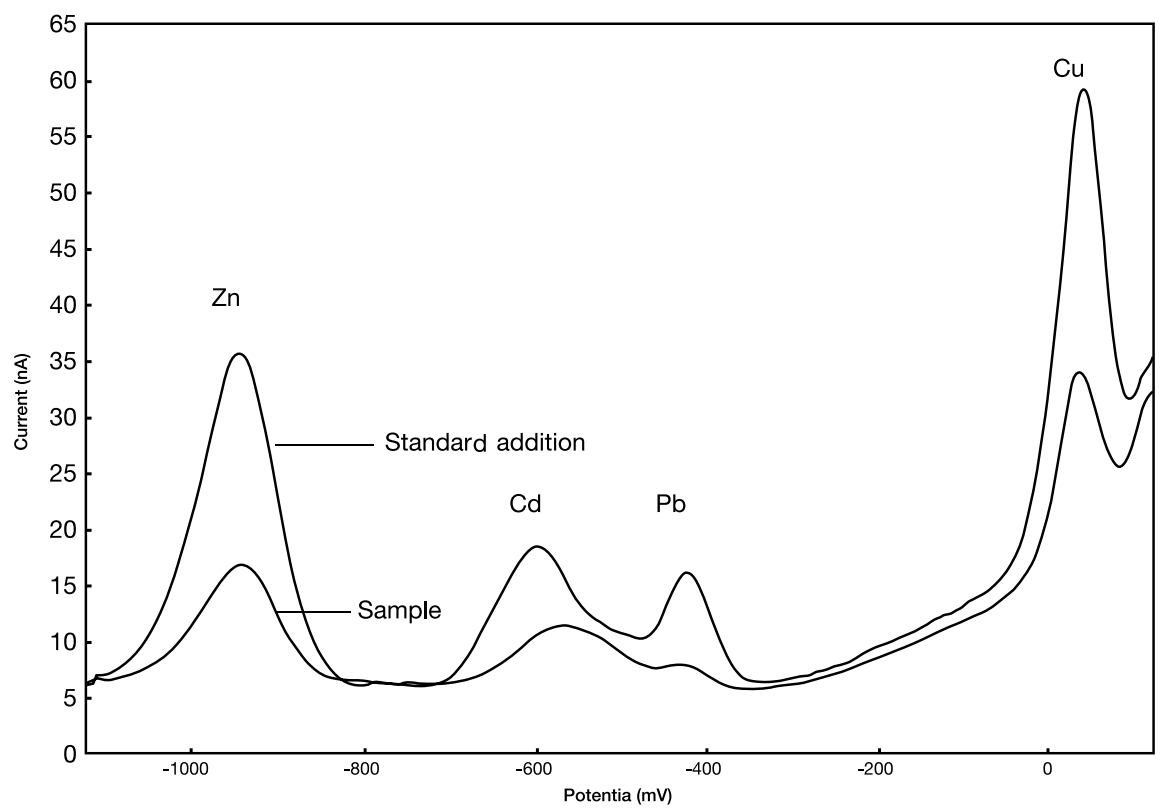

Fig . 2. Voltammetric curves for extracted feedstuff sample with adsorbent addition (extraction time $30 \mathrm{~min}$ )

First, concentrations of zinc in samples of feed mixtures without addition of the clinoptilolite were measured. Within the model situation used here, concentration of zinc in the digested samples represented the total concentration of zinc in the feed mixture, whereas concentrations found in extracts represented the available amount of free zinc in the digestive fluid tract.

The $95 \%$ confidence interval $(95 \% \mathrm{CI})$ for the concentration of zinc in the digest was found to be $(145 \pm 32.0) \mathrm{mg} \cdot \mathrm{kg}^{-1}$. Variability of the results expressed as the relative standard deviation (RSD) was $26.9 \%$. These results can be compared with the extraction data given in Table $2 \mathrm{a}$. Two conclusions could be drawn from the data given in Table 2a. First, the amount of zinc extracted under experimental model conditions is much lower (nearly ten times) than the total zinc concentration found in the feed mixture. This means at same time, that the available amount of zinc is relatively low. Secondly, the effect of the extraction time on the concentration of zinc in extracts is not statistically significant.

Table 2. Zinc concentrations in extracts of feed mixtures without and with the addition of clinoptilolite after various extraction time

\begin{tabular}{|c|c|c|c|}
\hline Extraction time $[\mathrm{s}]$ & Number of extracts & $95 \% \mathrm{CI}[\mathrm{mg} / \mathrm{kg}]$ & RSD [\%] \\
\hline \multicolumn{4}{|c|}{ (a) Samples without clinoptilolite addition } \\
\hline 30 & 5 & $18.9 \pm 3.69$ & 19.5 \\
\hline 60 & 5 & $16.8 \pm 8.57$ & 43.4 \\
\hline 120 & 8 & $15.6 \pm 3.91$ & 24.8 \\
\hline \multicolumn{4}{|c|}{ (b) Samples with clinoptilolite addition } \\
\hline 30 & 5 & $19.1 \pm 6.24$ & 27.7 \\
\hline 60 & 5 & $21.7 \pm 4.41$ & 17.2 \\
\hline 120 & 8 & $17.6 \pm 3.48$ & 24.1 \\
\hline
\end{tabular}


After the addition of $10 \mathrm{~g} \cdot \mathrm{kg}^{-1}$ of ZeoFeed into the feed mixture (which is the usual concentration used in practice) the following results were obtained. The $95 \% \mathrm{CI}$ for the total zinc concentration after the digestion of the sample was $(146 \pm 11.5) \mathrm{g} \cdot \mathrm{kg}^{-1}$, the calculated RSD was $9.6 \%$. It follows from the results that the addition of adsorbent did not affect the total zinc concentration in the feedstuff. The concentrations found in samples with added adsorbent found under the same conditions given above are presented in Table $2 \mathrm{~b}$. The same conclusions as before may be drawn from the results given in Table $2 \mathrm{~b}$. The available zinc concentrations were approximately ten times lower than the total concentration of the analyte in the feed mixture and there was no statistically significant evidence that the extraction time could affect the concentration of extracted free zinc.

The most important message based upon the simplified model of zinc extraction is that the addition of the adsorbent on the basis of clinoptilolite does not affect the concentration of free zinc in the extracts that may be considered as the available amount of zinc in the stomach of chicken.

\section{Adsorpce zinku obsaženého v krmivu pro drůbež na klinoptilolit}

Cílem práce bylo zjistit, zda adsorbent použitý v krmné směsi jako aditivum může ovlivnit koncentraci využitelného zinku. ZeoFeed, používaný často jako aditivum s adsorptivními účinky, zejména $\mathrm{v}$ krmných směsích pro drůbež, byl použit $\mathrm{v}$ koncentraci $10 \mathrm{~g} \cdot \mathrm{kg}^{-1}$. Podstatnou účinnou část ZeoFeedu tvoří minerál klinoptilolit. Pro analýzu zinku byly aplikovány dvě metody přípravy vzorků. Při stanovení celkové koncentrace byl použit mikrovlnami podporovaný vysokotlaký rozklad na mokré cestě směsí minerálních kyselin. Vedle toho pak extrakce krmiva za laboratorní teploty po dobu 30,60 a 120 minut zředěnou kyselinou chlorovodíkovou představovala zjednodušený model procesu probíhajícího v trávicím traktu. Koncentrace zinku byly měřeny metodou diferenční pulsní anodické rozpouštěcí voltametrie. Celková koncentrace zinku (průměr a meze 95\% intervalu spolehlivosti) stanovená v krmivu bez př́́davku klinoptilolitu byla $145 \pm 32,0 \mathrm{mg} \cdot \mathrm{kg}^{-1}, \mathrm{~s}$ př́́davkem klinoptilolitu pak $146 \pm 11,5 \mathrm{mg} \cdot \mathrm{kg}^{-1}$. Stanovené koncentrace využitelného volného zinku byly asi o jeden řád nižší. Rozdíly mezi množstvím zinku nalezeným v krmivu bez a s přídavkem klinoptilolitu byly, na hladině významnosti $\alpha=0,05$ statisticky nevýznamné. Také doba extrakce prakticky neovlivňovala množství volného zinku. Kromě zinku byly ve vzorcích krmiva dále stanoveny ještě měd' (esenciální prvek), kadmium a olovo (toxické prvky). Tyto hodnoty jsou předběžné a vyžadují ještě další verifikaci.

\section{Acknowledgements}

This research was supported by the Ministry of Education, Youth and Physical Training of the Czech Republic (Research Plan Veterinary Aspects of Food Quality and Safety, MSM 6215712402).

\section{References}

CABUK M, BOZKURT M, ALCICEK A 2004: Effect of Yucca schidigera and Natural Zeolite on Broiler Performance. Int J Poultry Sci 3: 1682-8356

ECKSCHLAGER K, HORSÁK I, KODEJŠ Z 1980: Vyhodnocování analytických výsledků. SNTL, Praha, $224 \mathrm{p}$.

HUWIG A, FREIMUND S, KAPPELI O, DUTLER H 2001: Mycotoxin detoxication of animal feed by different adsorbents. Toxicol Letters 122: 179-188

JANTOŠOVIČ J 1995: Choroby hydiny. DATAHELP, Košice, 101 p.

JURAJDA V 2003: Nemoci drůbeže a ptactva: metabolické poruchy, parazitární infekce a nemoci trávicího traktu. Veterinární a farmaceutická univerzita Brno, Brno, 167 p.

KARLSON P, DOENECKE D, KOOLMAN J 1994: Biochemie. Georg Thieme Verlag, Stuttgart, New York, 580 p.

MELENOVÁ L, CIAHOTNY K, JIRGLOVÁ H, KUSA H, RUZEK P 2003: Removal of ammonia from waste gases by adsorption on zeolites and their utilization in agriculture (In Czech). Chemické listy 97: 562-568

OLVER MD 1997: Effect of feeding clinoptilolite (zeolite) on the performance of three strains of laying hens. Brit Poultry Sci 38: 220-222 
SUCHÝ P, STRAKOVÁ E, VEČEREK V, KLOUDA Z, KRAČMAROVÁ E: 2006: The effect of clinoptilolitebased feed supplement on the performance of broiler chickens. Czech J Animal Sci 51: 168-173

TOMAŠEVIC-CANOVIC M, DAKOVIC A, MARKOVIC V, STOJSIC D 2001: The effect of exchangeable cations in clinoptilolite and montmorillonite on the adsorption of aflatoxin $\mathrm{B}_{1}$. J Serbian Chem Soc 66: 555-561

ZEOCEM, a.s. 2006: ZeoFeed [online] [cit. 2006-05-24]. Available at:_http://zeocem.sk/img/prod/pdf/zeofeed-sk.pdf 